\title{
Laparoscopic resection and intracorporeal anastomosis of perforated small bowel caused by fish bone ingestion
}

\author{
Ahmet Cem Dural, M.D., ${ }^{1}$ Muhammet Ferhat Çelik, M.D., ${ }^{2}$ Hakan Yiğitbaş, M.D., ${ }^{3}$ \\ Cevher Akarsu, M.D., ${ }^{1}$ Mahmut Doğan, M.D., ${ }^{1}$ Halil Alış, M.D. ${ }^{1}$ \\ 1'Department of General Surgery, Bakirköy Dr. Sadi Konuk Training and Research Hospital, İstanbul-Turkey \\ ${ }^{2}$ Department of General Surgery, Yedikule Surp Pırgic Armenian Hospital Foundation, İstanbul-Turkey \\ ${ }^{3}$ Department of General Surgery, Bağcılar Training and Research Hospital, İstanbul-Turkey
}

\begin{abstract}
Presently described is case of a 52-year-old man who was admitted to the emergency department with 3-day history of epigastric pain. Abdominal examination revealed diffuse tenderness and muscle guarding. Plain abdominal X-ray showed free subdiaphragmatic air. The patient underwent diagnostic laparoscopy with presumptive diagnosis of peptic ulcer perforation. Laparoscopy showed several inflamed, edematous jejunal loops with proximal obstruction and perforation by an impacted fish bone. Completely intracorporeal resection and anastomosis using laparoscopic linear stapler was performed and segment of resected bowel was removed through trocar site. Postoperative period was uneventful, and the patient was discharged on fourth day.
\end{abstract}

Key words: Fish bone; foreign body ingestion; perforation; small bowel.

\section{INTRODUCTION}

The majority of ingested foreign bodies (FB) are seamlessly excreted from the gastrointestinal tract by defecation. Perforation of the small bowel by FB is rare clinical finding, occurring in less than $1 \%$ of patients. ${ }^{\left[{ }^{[1]}\right.}$ Fish bones are the most commonly ingested organic objects and most common cause of FB perforation of the gastrointestinal tract. ${ }^{[1,2]}$

Preoperative diagnosis is usually challenging, since ingestion is mostly accidental. Intentional ingestion of FB is more commonly seen in psychiatric patients. ${ }^{[3]}$ Computed tomography is preferred screening method in the preoperative period for ingested bodies and related complications. ${ }^{[4]}$

Present report is description of a patient with acute abdomi-

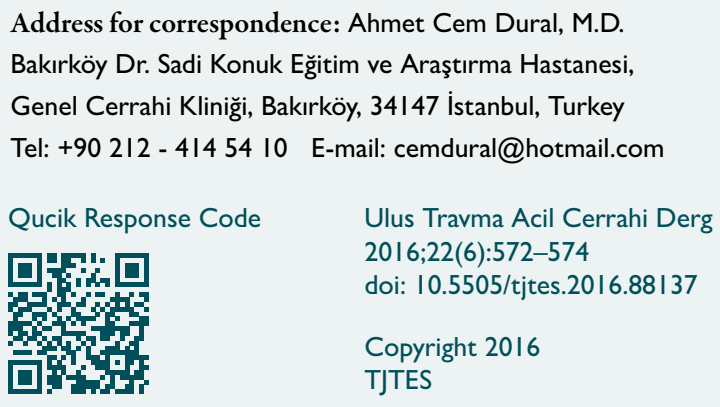

nal pain secondary to small bowel perforation caused by fish bone penetration of the jejunal wall mimicking perforated peptic ulcer.

\section{CASE REPORT}

A 52-year-old man was admitted to the emergency department with acute abdominal pain in the epigastric region that had been present for preceding 3 days. There was no nausea, vomiting, or diarrhea. Abdominal examination showed generalized tenderness and rigidity. Previous medical and surgical history was unremarkable except for diabetes mellitus and appendectomy. Laboratory tests indicated elevated white cell count of $11700 / \mathrm{mm}^{3}$ with $78 \%$ neutrophils, C-reactive protein level of $23.4 \mathrm{mg} / \mathrm{dL}$, and normal amylase level. Plain X-ray of the abdomen showed free air under the right diaphragm. Presumptive diagnosis was perforated peptic ulcer and emergency operation was scheduled. Diagnostic laparoscopy was performed.

After trocar and camera insertion via umbilical site, the abdomen was explored under $12 \mathrm{mmHg}$ carbon dioxide insufflation. Several inflamed, edematous small bowel loops and seropurulent fluid in the Douglas pouch were found. Two additional working ports were inserted into left upper and lower quadrants. Examination of the bowel loops revealed through-and-through perforation caused by fish bone on an- 
timesenteric side of the bowel loop, approximately $130 \mathrm{~cm}$ from the ileocaecal valve (Fig. I).

In addition to obstruction, localized inflammation around edge of perforation was noted. No other pathology was identified. Intracorporeal resection was performed approximately $5 \mathrm{~cm}$ proximal and distal to perforation and stricture site with laparoscopic linear stapler. After preparing 2 small enterotomies, 2 arms of $80 \mathrm{~mm} 3.8$ linear endostapler ( $3.8 \mathrm{~mm}$ staple)

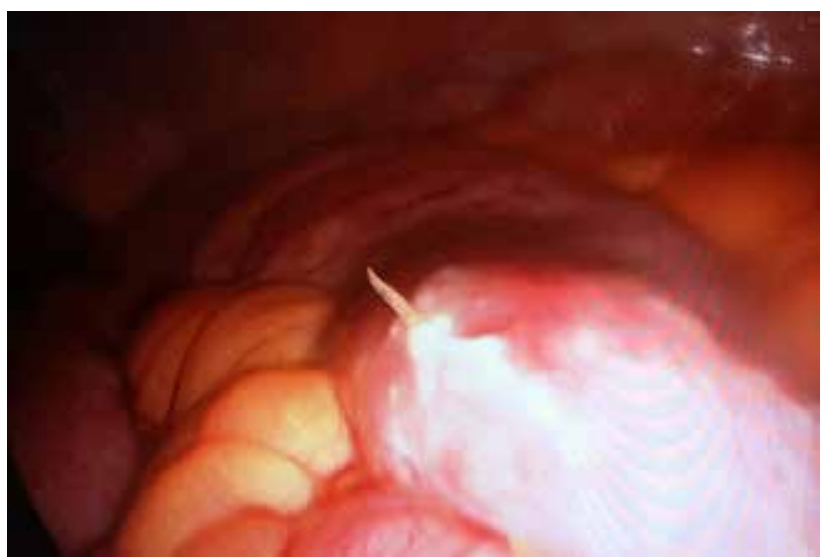

Figure 1. Through and through perforation site due to fish bone.
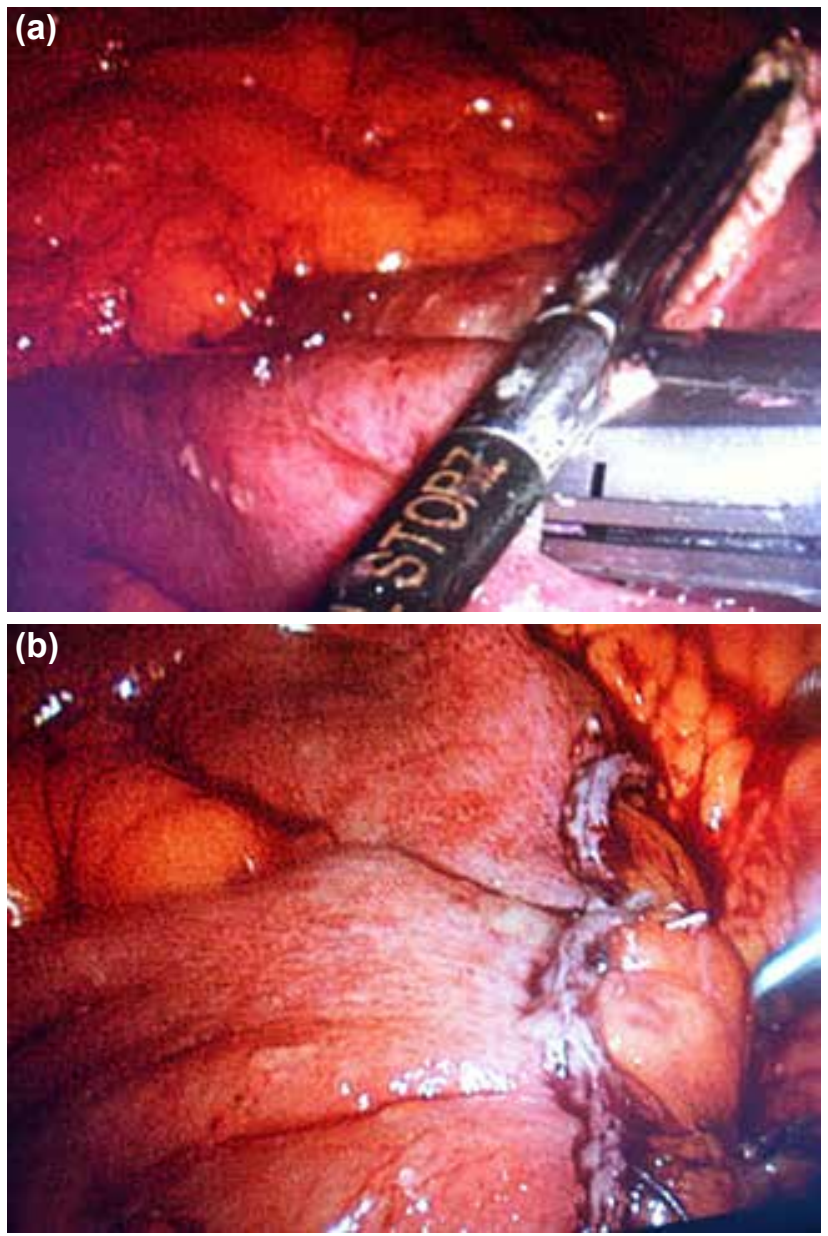

Figure 2. (a, b) Laparoscopic jejunal resection and intracorporeal anastomosis.

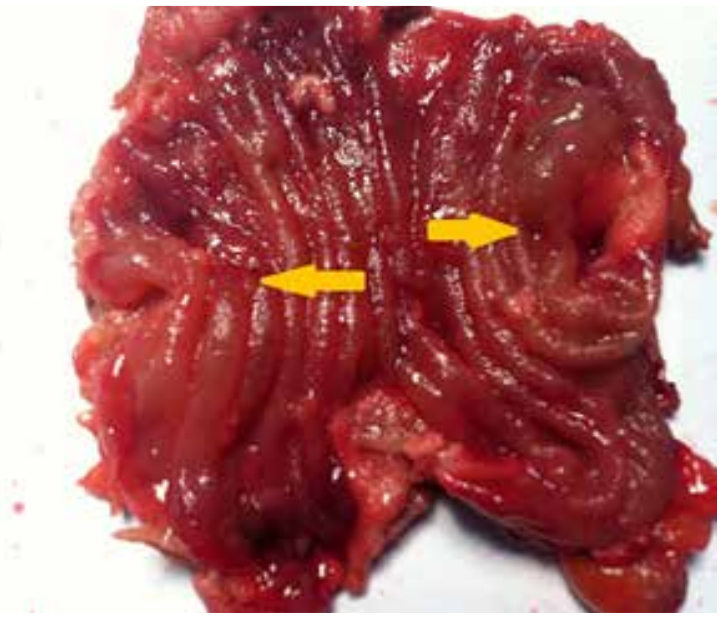

Figure 3. Resected bowel segment.

were inserted and fired (Fig. 2a). Second $80 \mathrm{~mm}$ linear stapler was placed perpendicularly in T-shape to 2 stapled bowel segments and full intracorporeal, functional, end-to-end anastomosis was performed (Fig. 2b).

Resected bowel was removed through $15 \mathrm{~mm}$ trocar site (Fig. $3)$. The patient underwent uneventful recovery and was discharged 4 days after procedure.

\section{DISCUSSION}

Accidentally ingestion of a FB is common in childhood, but may occur in any age group. The most common causes of intestinal perforation depending on FB are fish bones, chicken bones and sharp objects such as toothpicks in adults. ${ }^{[1,3]}$ However perforation by FB ingestion is a rare clinical condition. Perforation most often occurs at the ileocecal and rectosigmoid level following the stomach and duodenum at areas of angulation. ${ }^{[5]}$ Goh et al reported an FB perforation rate of $39 \%$ in the terminal ileum. ${ }^{[4]}$ Perforation of jejunum like this current case has a reported incidence of approximately $14.3 \%{ }^{[6]}$ Other possible regions of FB penetration are the hernia sac, Meckel's diverticulum, or the appendix.

Fishbone or non-radiopaque objects such as toothpicks can be diagnosed by ultrasonography. The role of CT in the evaluation of patients with FB ingestion has been previously described. ${ }^{[7]} A$ typical $C T$ finding of fish bone perforation is a hyperdense linear lesion surrounded by inflammation. CT imaging of the abdomen was not performed in this case. Initial laboratory and $\mathrm{X}$-ray findings were consistent with a presumptive diagnosis of hollow viscous organ perforation and diagnostic laparoscopy was therefore performed.

The complications due to clinically unsuspected foreign body ingestion may not be diagnosed by routine physical examination and standard diagnostic methods. Patients often present with localized or generalized peritonitis, abdominal mass or abscess. ${ }^{[3]}$ The most common radiographic finding is ileus followed by intra-abdominal free air. ${ }^{[3]}$ 
Endoscopic therapy, interventional radiological procedures, laparoscopy or laparotomy are used in the treatment of ingested foreign bodies. ${ }^{[4]}$ There are few cases of clinically unsuspected small bowel perforation due to foreign body ingestion diagnosed and treated by laparoscopy reported in the literature. ${ }^{[3]}$

In reported cases although resection is done laparoscopically, anastomosis is completed extracorporealy by the conventional method. ${ }^{[3,8,9]}$ To the best of our knowledge, this is the first case treated with total intracorporeal laparoscopic resection and anastomosis.

\section{Results}

In the differential diagnosis of acute abdominal pain, bowel perforation due to foreign body ingestion should be considered. A good questionnaire history with appropriate imaging will bring us to a correct diagnosis high probability.

\section{Acknowledgements}

The authors thank Dr. Burak Kankaya and Dr. Mustafa Gökhan Ünsal for their contributions, and Alexis Kofi Okoh for English language editing assistance.

Conflict of interest: None declared.

\section{REFERENCES}

1. Mutlu A, Uysal E, Ulusoy L, Duran C, Selamoğlu D. A fish bone causing ileal perforation in the terminal ileum. Ulus Travma Acil Cerrahi Derg 2012;18:89-91. Crossref

2. Lin CY, Wu FZ. Fish bone perforation of small intestine. QJM 2012;105:479-80. Crossref

3. Lunsford KE, Sudan R. Small bowel perforation by a clinically unsuspected fish bone: laparoscopic treatment and review of literature. J Gastrointest Surg 2012;16:218-22. Crossref

4. Goh BK, Chow PK, Quah HM, Ong HS, Eu KW, Ooi LL, et al. Perforation of the gastrointestinal tract secondary to ingestion of foreign bodies. World J Surg 2006;30:372-7. Crossref

5. Gül M, Aliosmanoğlu İ, Hakseven M, Çetinçakmak MG. Migration of two swallowed foreign bodies to different locations in the same case. Ulus Cerrahi Derg 2013;30:228-30.

6. Drakonaki E, Chatzioannou M, Spiridakis K, Panagiotakis G. Acute abdomen caused by a small bowel perforation due to a clinically unsuspected fish bone. Diagn Interv Radiol 2011;17:160-2.

7. Coulier B, Tancredi MH, Ramboux A. Spiral CT and multidetector-row CT diagnosis of perforation of the small intestine caused by ingested foreign bodies. Eur Radiol 2004;14:1918-25. Crossref

8. Law WL, Lo CY. Fishbone perforation of the small bowel: laparoscopic diagnosis and laparoscopically assisted management. Surg Laparosc Endosc Percutan Tech 2003;13:392-3. Crossref

9. Watanabe Y, Yamada D, Kobayashi K, Ryu S, Akashi Y, Miyoshi A. Single-incision laparoscopic surgery for small bowel perforation by a fish bone. Am Surg 2012;78:513-4.

\title{
OLGU SUNUMU - ÖZET
}

\section{Balık kılçı̆̆ı yutulmasına bağlı gelişen ince bağırsak perforasyonunun laparoskopik rezeksiyon ve anastomozu \\ Dr. Ahmet Cem Dural, ${ }^{1}$ Dr. Muhammet Ferhat Çelik, ${ }^{2}$ Dr. Hakan Yiğitbaş, ${ }^{3}$ Dr. Cevher Akarsu, ${ }^{1}$ Dr. Mahmut Doğan, ${ }^{1}$ Dr. Halil Alış ${ }^{1}$}

\author{
${ }^{1}$ Bakırköy Dr. Sadi Konuk Eğitim ve Araştırma Hastanesi, Genel Cerrahi Kliniği, İstanbul \\ ${ }^{2}$ Yedikule Surp Pırgiç Ermeni Hastanesi Vakfı, Genel Cerrahi Kliniği, İstanbul \\ ${ }^{3}$ Bağcılar Eğitim ve Araştırma Hastanesi, Genel Cerrahi Kliniği, İstanbul
}

Bu yazıda, balık kılçığına bağlı jejunal perforasyon sonrası üç gündür olan epigastrik ağrı şikayeti ile acil servise başvuran 52 yaşında erkek hasta sunuldu. Yapılan karın incelemesinde yaygın hassasiyet ve rebound mevcuttu. Ayakta direkt karın grafisinde diafragma altı serbest hava tespit edildi. Hastaya peptik ülser perforasyonu ön tanısılla tanısal laparoskopi uygulandı. Yapılan eksplorasyonda jejunal anslarda şiddetli enflamasyon, ödem, proksimal ince bağırsak anslarında obstrüksiyona bağlı dilatasyon ve balık kılçı̆̆ına bağlı perforasyon odağı görüldü. Perfore ince bağırsak ansı laparoskopik stapler ile rezeke edilip karıniçi anastomoze edildi ve perfore segment trokar yerinden karın dışına alındı. Hastanın ameliyat sonrası takiplerinde sorunu olmadı ve dördüncü günde taburcu edildi. Bu örnekte balık kılçığına bağlı ince bağırsak perforasyonu ve obstrüksiyon gelişen hastada laparoskopik rezeksiyon ve anastomoz tanımlanmıştır.

Anahtar sözcükler: Balık kııçı̆̆ı; ince bağırsak; perforasyon; yabancı cisim yutulması.

Ulus Travma Acil Cerrahi Derg 2016;22(6):572-574 doi: 10.5505/tjtes.2016.88।37 